\title{
Reverse-phase phosphoproteome analysis (RPMA) of signaling pathways induced by HTLV-1 infection
}

\author{
Taissia G Popova' ${ }^{1}$, Aarthi Narayanan', Lance Liotta², Emanuel F Petricoin III', Charles Bailey ${ }^{1}$, Kylene Kehn-Hall', \\ Fatah Kashanchi ${ }^{1,3^{*}}$
}

From 15th International Conference on Human Retroviruses: HTLV and Related Viruses

Leuven and Gembloux, Belgium. 5-8 June 2011

Phosphorylation plays a key role in regulating many signaling pathways. Cell fate decisions in response to extracellular agents, including pathogenic invaders, are commonly mediated by phosphorylation-regulated signaling cascades that transduce signals into stimulusspecific actions, such as changes in gene expression pattern. Here we utilized a novel approach where we infected cells with HTLV wild type and mutant clones and analyzed the phosphorylation status of the cells. For phosphoproteomic analysis the cell lysates were printed onto nitrocellulose membrane slides. Each slide was then probed with one of 360 different antibodies specific against phosphorylated or total forms of signaling proteins. The antibodies were selected to monitor the molecular networks involved in host responses most likely affected by virus exposure, namely survival, apoptosis, inflammation, growth, differentiation, and immune response. This RPMA technique was extensively validated in our previous studies with regard to specificity of antibodies, sensitivity, and accuracy of phosphoprotein detection in cell lysates. Changes in NFkB, SAP/ JNK, ERK and AKT and against phosphorylated form of p-38 and PTEN will be discussed.

\footnotetext{
Author details

'George Mason University, Department of Molecular and Microbiology, National Center for Biodefense and Infectious Diseases, Manassas, VA, 20110, USA. ${ }^{2}$ George Mason University, Center for Applied Proteomics and Molecular Medicine, Manassas, Virginia, 20110, USA. ${ }^{3}$ The George

* Correspondence: fkashanc@gmu.edu

'George Mason University, Department of Molecular and Microbiology, National Center for Biodefense and Infectious Diseases, Manassas, VA, 20110, USA

Full list of author information is available at the end of the article
}

Washington University Medical Center, Department of Microbiology, Immunology, and Tropical Medicine, Washington, DC, 20037, USA.

Published: 6 June 2011

doi:10.1186/1742-4690-8-S1-A177

Cite this article as: Popova et al:: Reverse-phase phosphoproteome analysis (RPMA) of signaling pathways induced by HTLV-1 infection. Retrovirology 2011 8(Suppl 1):A177.

Submit your next manuscript to BioMed Central and take full advantage of:

- Convenient online submission

- Thorough peer review

- No space constraints or color figure charges

- Immediate publication on acceptance

- Inclusion in PubMed, CAS, Scopus and Google Scholar

- Research which is freely available for redistribution

Submit your manuscript at www.biomedcentral.com/submit
Biomed Central

\section{Biomed Central}

(c) 2011 Popova et al; licensee BioMed Central Ltd. This is an open access article distributed under the terms of the Creative Commons Attribution License (http://creativecommons.org/licenses/by/2.0), which permits unrestricted use, distribution, and reproduction in any medium, provided the original work is properly cited. 